\title{
喉頭の自律神経支配
}

$\begin{array}{llllll}\text { 久充・豊 田 健 司・園 田 隆 郎 } \\ \text { 紀 平 晋 也・宇 野 敏 行 } & \\ \text { 八 木 正 人・村 上 } & \text { 泰 } & \end{array}$

\section{Autonomic Innervation of the Larynx}

\author{
Yasuo Hisa, Kenji Toyoda, Takao Sonoda, Shinya Kihira, \\ Toshiyuki Uno, Masato Yagi and Yasushi Murakami
}

\begin{abstract}
The autonomic innervation of the larynx has been studied by fluorescence histochemistry and immunohistochemistry. In the laryngeal sympathetic nervous system, many problems has been solved using fluorescence histochemistry (Falck-Hillarp method) and immunohistochemistry for tyrosine hydroxylase. There are still many problems to be studied for the laryngeal parasympathetic nervous system. Advantages and disadvantages of the morphological techniques that have been used in this research field including ours were discussed in detail. Sympathetic nerve fibers were identified in the intrinsic laryngeal muscles and mucosa. In the intrinsic muscles, sympathetic nerve fiber running along the muscle fiber was observed. This finding suggests the existence of the direct sympathetic innervation of the intrinsic muscles. Using 5-hydroxydopamine technique, sympathetic innervation of the laryngeal gland was electron-microscopically clarified. Laryngeal nerves were also clarified to contain many sympathetic nerve fibers and the existence of the perivascular sympathetic innervation of the larynx was considered to be negative. CGRP immunoreactivity in the laryngeal autonomic nervous system was also discussed.
\end{abstract}

Key words : larynx, autonomic nerve, fluorescence histochemistry, histochemistry, immunohistochemistry, neuropeptide

$$
\text { はじめに }
$$

自律神経系は，不随意的，反射的調節によって臓器の動 きをコントロールし，呼吸，循環，消化，吸収，生殖，分 泌など，生命の維持に必須のものであり，喉頭においても 重要な役割を担っていると考えられる。しかし，10年前ま では喉頭の自律神経支配の詳細に関しては，極めて不確実 なものであった。その一例をあげるならば，喉頭内の自律 神経線維の確実な同定もされず，またその線維の喉頭への 経路すら明らかではなかった。第16回喉頭基礎問題研究会 が, 約10年前の昭和 56 年 5 月に，「喉頭基礎研究の展望」 というテーマで開かれた際に，我々は喉頭の自律神経系の 形態学的研究上の問題点について報告した1)。これらの問 題点が現在までにどのように解決されてきたか，何が現在 も問題点として残っているのか，また，新たにどのような ことが問題となってきたかを本論文で明らかにすることに より，今後の本領域における研究の指針としたい。

$$
\text { 研究法について }
$$

喉頭における交感神経線維はその細胞体を頸部交感神経 節に有し, 副交感神経線維のそれは喉頭内あるいは喉頭神
経内に有していると考えられる. 節前神経の古典的な伝達 物質は交感神経, 副交感神経の両者ともアセチルコリンで あること，節後神経のそれは交感神経系ではノルアドレナ リンであり，副交感神経系ではアセチルコリンであること は良く知られているところである（図 1)。よって，何ら かの方法でこれらの物質を同定する事が，それぞれの神経 を同定する事となる。まずこれらの方法について検討した い. 10年前には, 交感神経の同定には, 光顕的に蛍光組織 化学法が, その終末の電顕的検索には5-hydroxydopamine (5-OHDA）法が，すでに確立されていた。一方，副交感 神経の同定には，主に $\mathrm{AChE}$ 染色が光顕的，電顕的に用 いられてきたが，本法は閒接的な証明であり確実なものと は言い難く, 中枢神経系に抒いて Choline Acetyltransferase (ChAT) の免疫組織化学的証明がなされ始めてお $\eta^{2)}$ ，この方法を末梢における副交感神経系の同定に用い れば，より正確な結果が得られるであろうと考えられた。

ChATの免疫組織化学法を用いて疑核の運動神経細胞内 のAChの同定には成功した ${ }^{3)}$ 。しかし，喉頭内の副交感 神経線維の同定にはいまだ成功していない.よって，本論 文では，主に交感神経系の問題点について検討したい。副 交感神経系に関しては今後の検討が待たれるところである. 


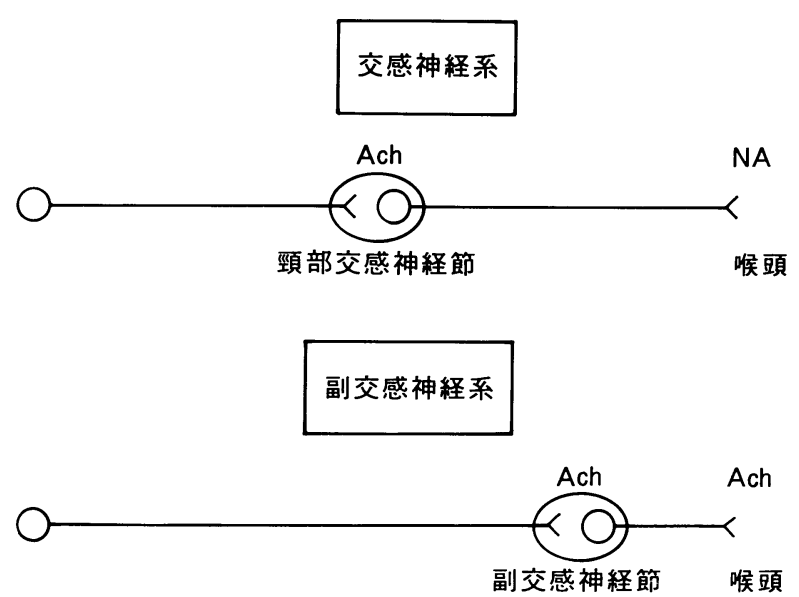

図1 自律神経系の模式図とその古典的神経伝達物質

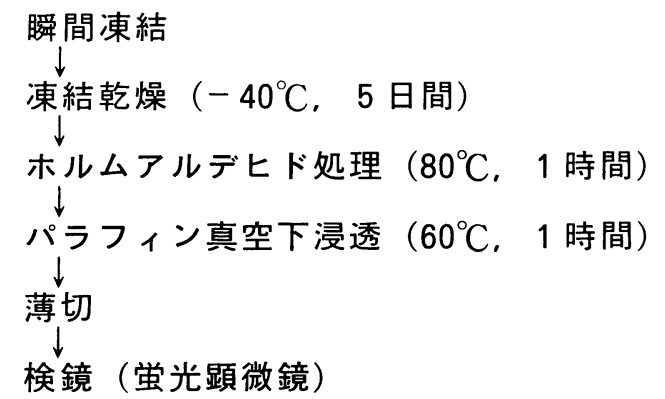

図2 蛍光組織化学法の実際

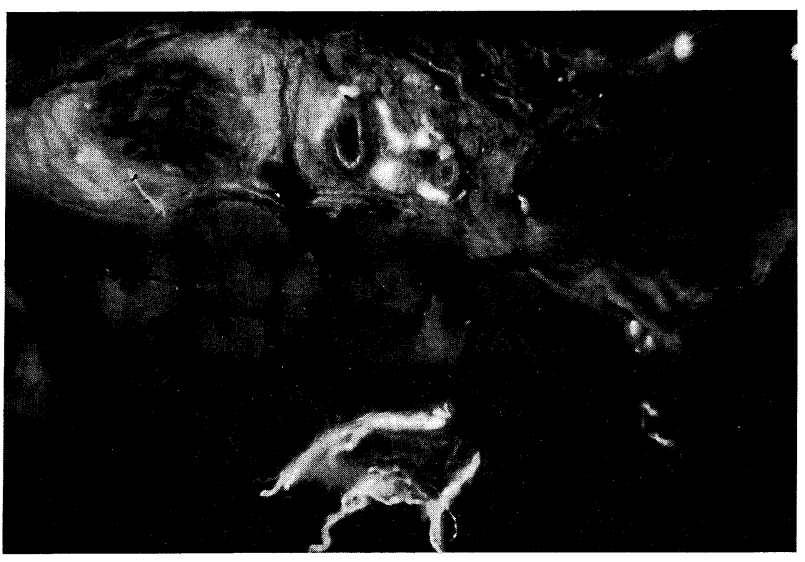

図 3 Falck-Hillarp 法で処理した甲状披裂筋. 血管周囲に 交感神経線維が蛍光を有した線維として観察される。

1. 蛍光組織化学法

ノルアドレナリンもそれに含まれるカテコラミンの組織 化学的な証明として, 蛍光組織化学法が用いられてきた。 その原理は生体モノアミンやその前駆物質が，ホルムアル デヒドと反応し, 乾燥タンパク質を触媒として蛍光を発す る物質となる事を利用したものである ${ }^{4)}$. 蛍光組織化学法
のひとつである Falck-Hillarp 法5) の手順を図 2 に示す. 手間と時間とともに特殊な設備を要する．また，満足すべ き試料をコンスタントに得ることが非常に困難であるとい う難点がある.

Falck-Hillarp 法ののちに改良されたものに湿式法 ${ }^{6,7}$ がある．本法の利点は簡便である事，そして高感度である 事だが，その反面，クリオスタット切片やビブラトーム切 片を用いるため, 薄切標本の作製が困難という欠点がある. いずれの方法を用いるかをその時々に応じて，よく検討す る事が大切である.

2. 5-hydroxydopamine (5-OHDA) 法

アミン線維の電顕的証明には 5-hydroxydopamine (5OHDA）法が用いられてきた ${ }^{8)}$. False transmitter であ る5-OHDA が内在性アミンの代わりに入り込むとともに， オスミウム black を有する性質を利用したものである. 投 与法に関しては, 総頸動脈注入法と喉頭局所内注入法の両 者について検討した．局所内注入した後，注入部位から少 し離れた部位から試料を作製することによって，良好な結 果を得た ${ }^{9}$.

なお，本研究に際し，実験動物としてはイヌをすべての 実験で用いた。

\section{0年前の問題点への対応とその結果}

では，上記の方法を用いて，10年前の種々の問題点が現 在どのような状況にあるかについて述べる.

1. 喉頭内自律神経線維の同定

10年前には，喉頭内自律神経線維の正確な同定が一切な されてなかった。そこで，まず，内喉頭筋を Falck-Hillarp 法で処理した．図 3 に甲状披裂筋を示すが，血管周囲にノ ルアドレナリン線維が蛍光を有した線維として観察される. これは世界で初めて確実に同定された喉頭内交感神経線維 である.内喉頭筋内の血管周囲には図 3 のような細動脈レ ベルも含め, 多くの交感神経線維の分布が確認された。 Shin et al ${ }^{10)}$ は喉頭の血流調節に交感神経が関与してい る可能性を報告したが，本研究の結果からも喉頭筋内の血 流調節に交感神経が大いに関与していると考えられた。

図 4 は，声門下粘膜を Falck-Hillarp 法で処理したもの である．粘膜上皮内にはノルアドレナリン線維を認めない が，固有層には多くのノルアドレナリン線維が観察された. 喉頭腺周囲にも分布しており，交感神経の喉頭腺分泌への 関与が示唆された。そこで，先に述べた 5-OHDA 法を用 いて, 喉頭腺での交感神経線維終末を電顕的に観察した。 交感神経終末と考えられる，5-OHDA を取り込み濃染し た小胞を含む終末が，喉頭腺周囲の血管以外の腺上皮，筋 上皮近辺にも観察された。これらはすべて自由神経終末と して観察された。これらから，喉頭腺に対する交感神経支 配の存在がほぼ証明できたと考えられた8).

次なる問題点は, 果たして従来言われているような, 内 喉頭筋への直接的な交感神経支配 $\left.{ }^{11}, 12\right)$ が存在するのか否 かということである. 内喉頭筋を Falck-Hillarp 法で処理 


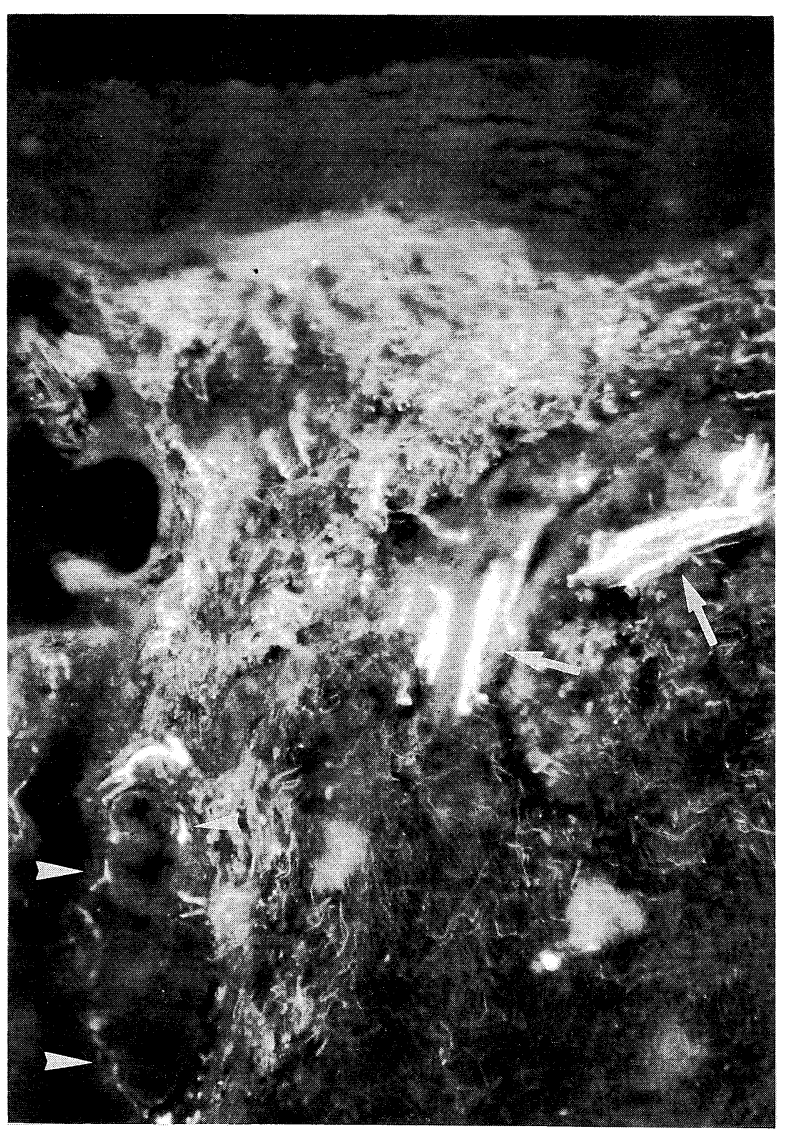

図4 Falck-Hillarp 法で処理した声門下粘膜. 粘膜上皮内 には交感神経線維を認めないが, 固有層には多く認め $(\rightarrow)$ ，腺周囲にも分布しているのが観察された

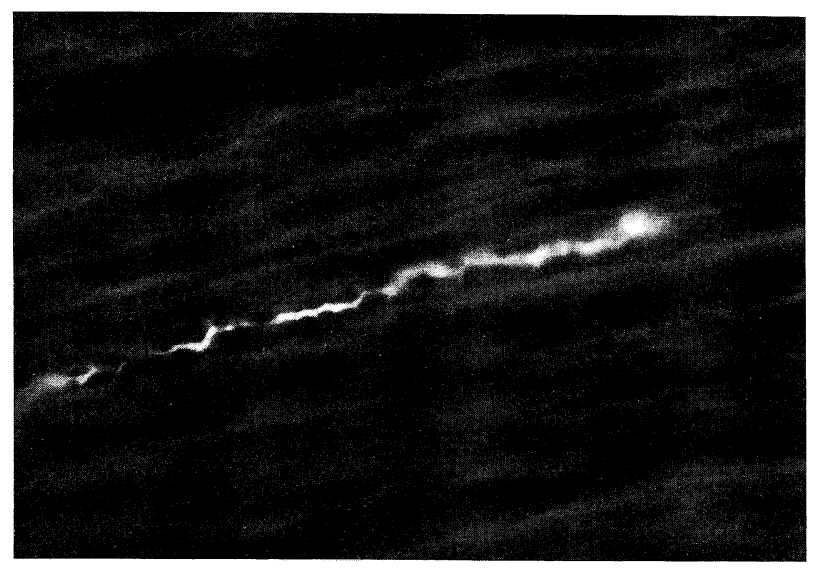

図 5 Falck-Hillarp 法で処理した甲状披裂筋. 筋線維に平 行して走る交感神経線維が観察される.

すると，筋線維周囲，あるいは筋に伴走するノルアドレナ リン線維がときに観察される (図 5 )。これらのノルアド レナリン線維が筋に直接終末しているか否かは今後更に検 討する必要があると考えられる。

2. 喉頭神経における自律神経線維の構成

各喉頭神経に多くの無䯣神経線維が含まれていることは

$$
\text { ×結紮 }
$$

○挫滅
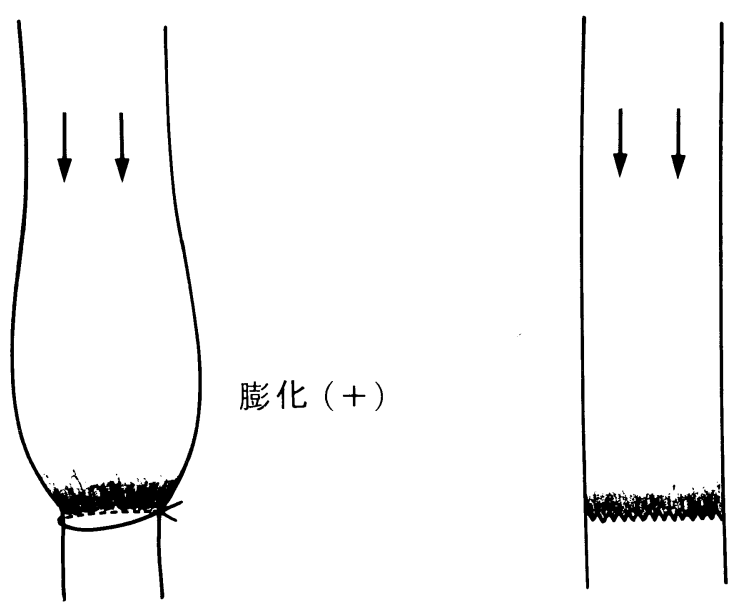

図 6 神経束内での伝達物質の同定

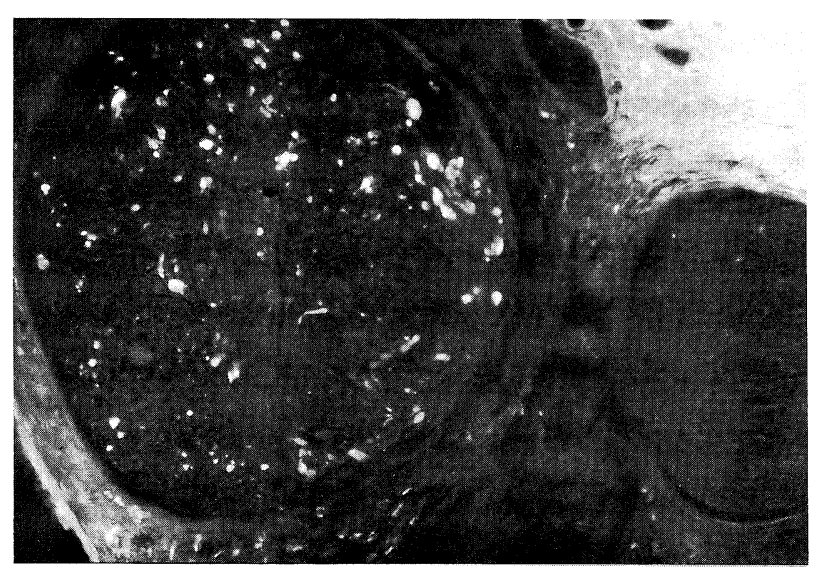

図7 Falck-Hillarp 法で処理した上喉頭神経内枝. 多くの 交感神経線維が散在性に含まれているのが観察される.

良く知られているが ${ }^{13 \sim 18)}$, 確実なる自律神経線維の同定 はなされてなかった。

ここで, 神経束内での伝達物質の同定における注意点を 述べる，伝達物質は軸索流に乗って細胞体から末梢に運ば れることが多い。よって, 軸索のある部位で伝達物質を同 定するには，何らかの方法で軸索流を止めることによって， その部位に伝達物質を貯留させることが必要となってくる. 伝達物質を同定したい部位の末梢を結紮する方法と挫滅す る方法の両者を試したが, 図 6 のごとく, 結紮した場合に は中枢側に膨化が認められ, 挫滅の方が優れていると考え られた。

そこで, 上喉頭神経内枝，外枝および下喉頭神経をそれ ぞれ喉頭入口部において挫滅した後, Falck-Hillarp 法で 処理した。 上喉頭神経内枝には大小 4,5 本の神経束があ 
り，そのすべてに多くのノルアドレナリン線維が散在性に 含まれていることが判明した（図７）。また，上喉頭神経 外枝にもノルアドレナリン線維が結構含まれているのが観 察された。一方, 下喉頭神経では前枝に少数のノルアドレ ナリン線維が認められたものの，主に後枝に多く含まれて いることが判明した ${ }^{19)}$. 図 8 は下喉頭神経後枝で観察され た像であるが，これらから，下喉頭神経中に散在していた ノルアドレナリン線維が, まず周辺部に集まり, その後, ノルアドレナリン線維だけが束となって, 下喉頭神経から 分離していくのではないかと考察した.

3. 上, 下喉頭動静脈を介する喉頭の自律神経支配の有無

さて，多くの教科書に自律神経線維は上，下喉頭動静脈 を介して喉頭に至ると記されている。しかし，その根拠と なる点については不明である，一方，前述のごとく各喉頭 神経中には多くの交感神経線維が含まれていることが判明 した。 そこで, 上, 下喉頭動静脈を保存した後, 上喉頭神 経内枝，外枝そして下喉頭神経を喉頭入口部で切断し，1 週間後に，喉頭を摘出し，Falck-Hillarp 法に供した。

内喉頭筋，喉頭腺に見られたノルアドレナリン線維は消 失し，全く観察されなかった。このことから，上，下喉頭 動静脈を介した交感神経系の喉頭支配は存在しないと考え られた。すなわち, 喉頭への交感神経線維の経路は喉頭神 経のみであると考えられる.

\section{その後の新展開}

以上のように，10年前には疑問であった多くの事項が解 決された。一方, 科学の進歩にともない, 本領域でも, 研 究上の新展開が見られる。その一つに, 免疫組織化学法の 導入がある ${ }^{20)}$. 本法の理論と実際は成書を参考にされた

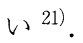

1. Tyrosine Hydroxylase に対する免疫組織化学法 免疫組織化学法の自律神経系研究への応用には次のよう なものが考えられる．副交感神経系ではアセチルコリンゃ

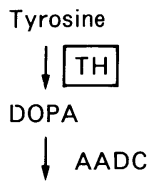

Dopamine

$\begin{array}{cl}\downarrow \mathrm{DBH} & \mathrm{TH}: \text { tyrosine hydroxylase (分子量 } 25 \times 10^{4} \text { ) } \\ \text { Noradrenaline } & \text { AADC : aromatic amino acid decarboxylase } \\ \downarrow \text { PNMT } & \text { DBH : dopamine- } \beta \text {-hydroxylase } \\ \text { Adrenaline } & \text { PNMT : phenylethanolamine } \\ \text { N-methyltransferase }\end{array}$

図 9 Catecholamine の合成
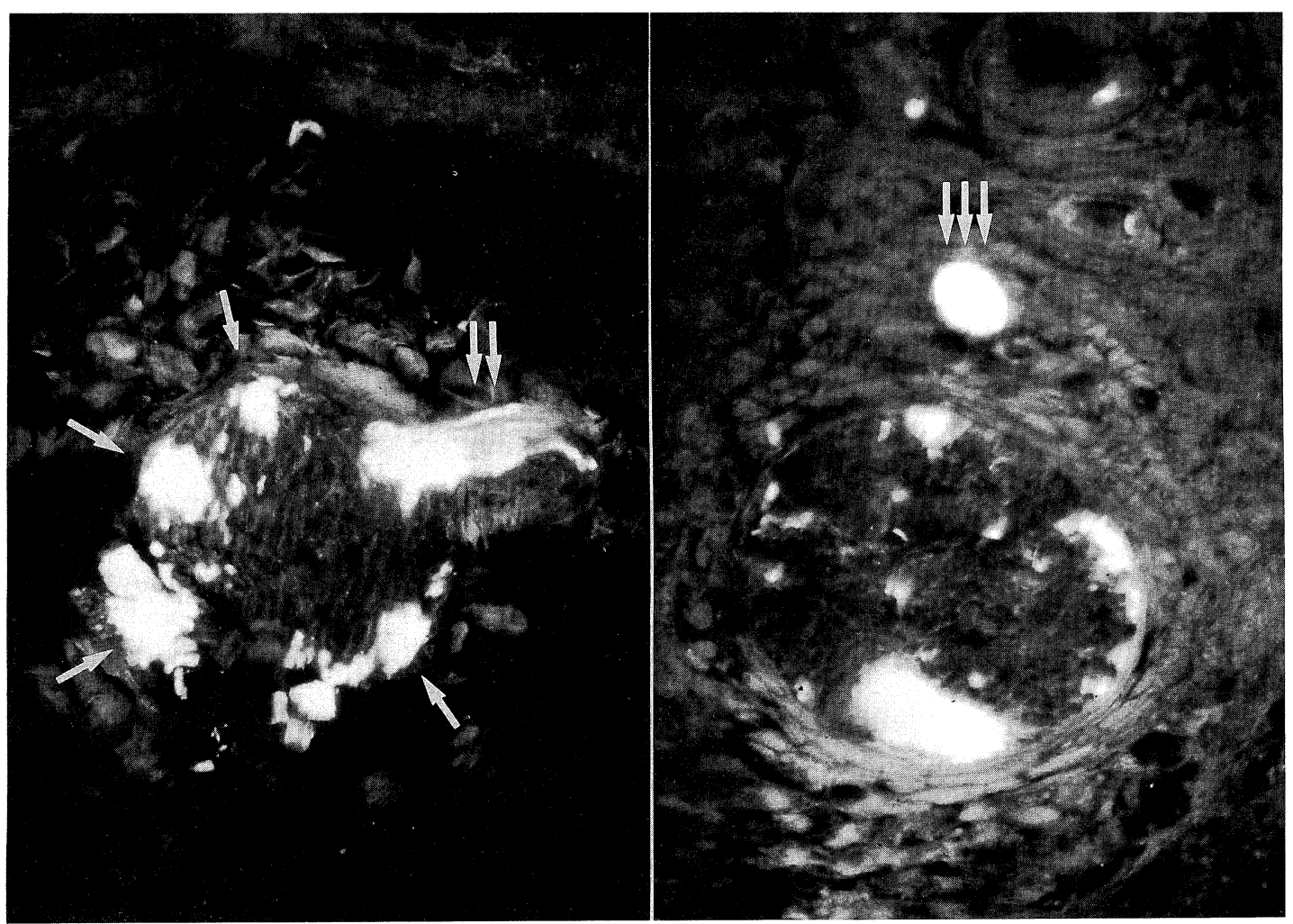

図 8 Falck-Hillarp 法で処理した下喉頭神経後枝で観察された二つの異なった像. 神経 に散在していた交感神経線維がまず，周辺部に集まり $(\rightarrow)$ ，その後，交感神経線 維だけが束となって $(\rightrightarrows)$, 分離していく $($ 马) のではないかと考えられる. 
前述の Choline Acetyltransferaseの, そして交感神経系 ではノルアドレナリンや Tyrosine Hydroxylase の免疫 組織化学的証明である. 実際に, 川副ら 22$)$ は喉頭におけ る交感神経線維をノルアドレナリンに対する抗体を用いて 免疫組織化学的に証明している。ここでは, 我々が行って いる Tyrosine Hydroxylase (TH) に対する免疫組織化 学法について述べる. 本法は, ノルアドレナリンも含まれ るカテコラミンの律速酵素である TH（図 9 ）に対する抗 体を用いて, 同酵素の存在を免疫組織化学的に証明するこ とにより，カラコラミンの存在を間接的に証明するもので ある，喉頭においてこの酵素の存在が証明されれば，それ はノルアドレナリンの存在, すなわち交感神経の証明とな る訳である。

図10は甲状披裂筋を $\mathrm{TH}$ 免疫組織化学法で処理したもの である、甲状披裂筋中の血管周囲にV V a ricosity を有した $\mathrm{TH}$ 陽性線維が観察された。図11に喉頭腺を示すが，腺周 井にもVaricosity を有した TH 陽性線維が観察された.

ここで, 本法と前述の蛍光組織化学法とを比較すると, いずれもカテコラミンの証明に用いられるわけであるが,

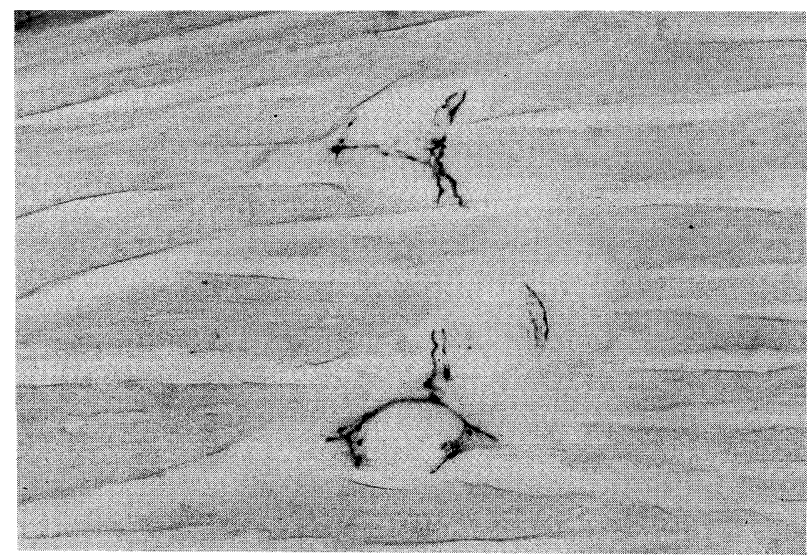

図10 TH 免疫組織化学法で処理した甲状披裂筋. 血管周囲 に varicosityを有した TH 陽性線維が観察される。

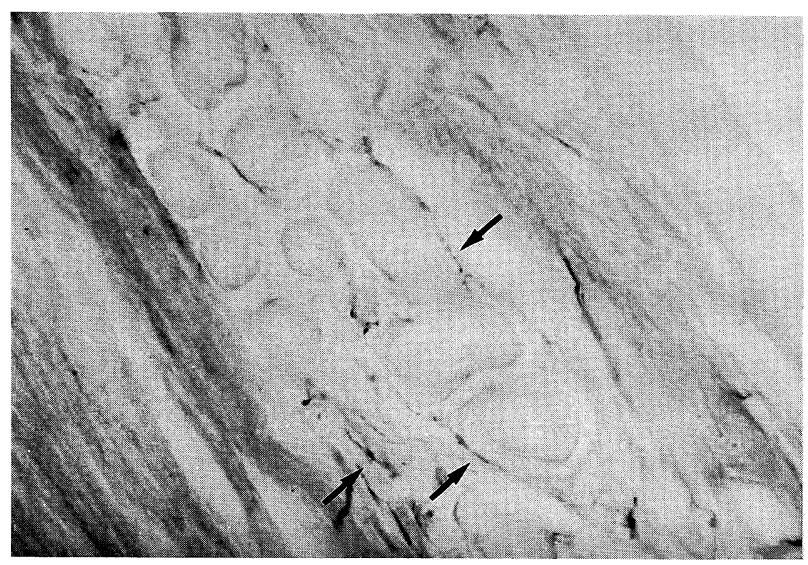

図11 TH 免疫組織化学法で処理した喉頭腺. 腺周囲に varicosity を有した TH 陽性線維 $(\rightarrow)$ が観察される.
四12のごとく $\mathrm{TH}$ 免疫組織化学法のほうが優れていると考 えられる. しかし, 蛍光組織化学法にも利点があり, いず れの方法を選択するかを, 研究の用途によって考慮するこ とが肝要である。

2.ニューロペプチドに対する免疫組織化学法

免疫組織化学法の発展とともに, 最近, 各種のニューロ ペプチドが自律神経系において, 神経伝達物質あるいは神 経調節物質としての役割を担っていることが明らかとなっ てきた (図13) ${ }^{23)}$. 喉頭においても多くのニューロペプチ ドの存在がすでに知られている24 26).これらは主に古典 的伝達物質であるノルアドレナリンあるいはアセチルコリ ンと共存して, 神経機能の精巧な調節を行っていると考え られるが，その詳細は現在いまだ不明であり，今後の発展 が待たれる.今回は喉頭の自律神経系に存在すると考え られる各種ニューロペプチドのうち, Calcitonin generelated peptide (CGRP) に限って, その喉頭における 分布について述べる（なお，CGRP は喉頭の知覚神経系 にも存在するが26), 本論文ではこの点については言及しな w).

\begin{tabular}{|c|c|c|}
\hline & 蛍光組織化学 & THの免疫組織化学法 \\
\hline 物 質 & $\begin{array}{l}\text { カテコラミン自身が } \\
\text { 閉環する. }\end{array}$ & $\begin{array}{l}\text { カテコラミン合成の } \\
\text { 律速酵素. }\end{array}$ \\
\hline 手 技 & $\begin{array}{l}\text { 繁雑，確実性が低い. } \\
\text { 退光する. }\end{array}$ & $\begin{array}{l}\text { 再現性が高い. } \\
\text { DAB反応で永久保存が } \\
\text { 可能。 }\end{array}$ \\
\hline 感 度 & 低い。 & 高い（特に線維，終末)。 \\
\hline その他 & & $\begin{array}{l}\text { counter stainingが可能. } \\
\text { 電顕的検索が可能. }\end{array}$ \\
\hline
\end{tabular}

図12 蛍光組織化学と免疫組織化学の比較

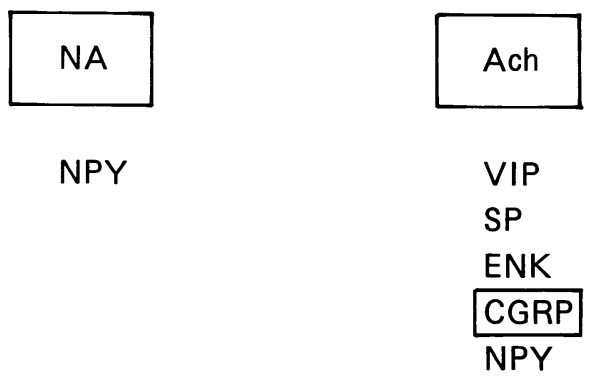

図13最近, 各種のニューロペプチドが自律神経系において, 古典的神経伝達物質であるノルアドレナリンやアセチ ルコリンと共存し，神経伝達物質あるいは神経調節物 質としての役割を担っていることが明らかになってき た。 


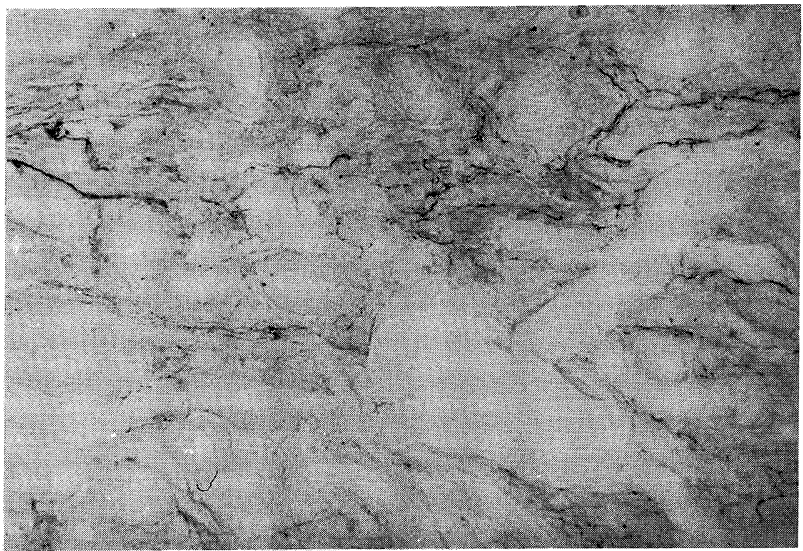

図14 CGRP 免疫組織化学法で処理された喉頭室粘膜. 喉 頭腺にも多くの CGRP 陽性線維が分布しているのが 観察される.

一般に, CGRP は自律神経系では副交感神経節後神経 においてAch と共存するといわれている ${ }^{23)}$. 図14は喉頭 室粘膜を CGRP 免疫組織化学法で処理したものである. 喉頭腺にも多くの CGRP 陽性線維が分布しているのが観 察される. 自律神経線維と考えられる CGRP 陽性線維は これ以外に, 喉頭粘膜固有層や内喉頭筋内の血管の周囲に も多く観察された。これらの所見より，やはり，CGRP は喉頭においても副交感神経系に関与していると考えられ る.

\section{今後の問題点}

交感神経系の諸問題については，今まで述べてきたよう に，末梢に関するかぎりほぼ解決されてきたように思える. しかし, 副交感神経系については, その研究手技上の問題 もあって多くのことが未解決のままである. よって, 今後 はこの点を主なる研究対象としていく必要があると思われ る。そのためには，まず実験手法を検討しなければならな い. 何故, ChATの免疫組織化学的証明が中枢で可能であ るのに末梢でできないのか. 中枢における ChAT と末梢 におけるChAT の抗原性に何か相違があるのだろうか. 今後の検討が待たれる.

もし，どうしても ChATの末梢における証明が不可能 であるのなら，アセチルコリンそのものを免疫組織化学的 に証明できないだろうか.すでにアセチルコリンの抗体自 体はすでに作製されており，また，市販もされている。し かし，ここにひとつ問題がある。それは固定法である。ア セチルコリンを固定するのが極めて難しいのは，良く知ら れているところである. ある物質に対して, いくら良い抗 体が得られても, その物質の固定ができなければ, 免疫組 織化学的にその物質の存在を証明することは不可能である. もしアセチルコリンに対する最適な固定法が見いだされた ならば, この分野における研究は飛躍的に発展すると考え られる。

次なる今後の問題点は, やはり, 自律神経系における古
典的神経伝達物質であるノルアドレナリンおよびアセチル コリンと他の神経伝達物質あるいは神経調節物質(ニュー ロペプチド等）との相互作用の詳細なる究明であろう.

古典的神経伝達物質とニューロペプチドの相違点のひと つは生合成の場の違いである. 古典的神経伝達物質は細胞 体でも合成されるが，神経終末での生合成のほうが多く， その生合成酵素活性は, 最終産物である神経伝達物質によ りフィードバック調節を受けているという 27, 28). 一方, 神 経ペプチドは細胞体で合成され, 軸索流によって神経終末 に運ばれてくる. 生合成の場が違うと, 遊離した後の伝達 物質の補充に差が見られるのは明らかである27). また, 古 典的神経伝達物質に比べ，ニューロペプチドの含量は著し く少ないことからも, 強い長時間の刺激で, 古典的神経伝 達物質に比べ容易に減少, 枯渴すると考えられる ${ }^{27)}$.この ような両者が喉頭の自律神経系において, どのような相互 作用を有しているのか, 今後, 形態学的手法と生理学的手 法を連動させることによって, 究明していくことが重要で あると思われる。

\section{結語}

以上, 喉頭の自律神経系に関する形態学的研究における 過去10年間の成果と今後の問題点について述べた. 多くの 疑問点が現在までに明らかとなったが，未だ不明な点も多々 あり, 今後の本領域での研究の更なる発展が望まれる.

\section{文献}

1）久 育男: 喉頭解剖, 自律神経. 第16回喉頭基礎問 題研究会資料：27２9, 1981.

2) Kimura $\mathrm{H}$ et al: The central cholinergic system studied by choline acetyltransferase immunohistochemistry in the cat. J Comp Neurol 200 : 151 201, 1981.

3）久育男ほか: イヌ疑核運動神経細胞の choline acetyltransferase に関する免疫組織化学的研究. 日耳鼻 $91: 1648,1988$.

4）田中千賀子, 吉田信芳：神経伝達物質の組織化学： アミンニューロン．組織細胞化学1980（日本組織細 胞化学会編) 261 271, 学際企画, 東京, 1980.

5) Falck B et al : Fluorescence of catecholamines and related compounds condensed with formaldehyde. J Histochem Cytochem 10:348 354, 1962.

6) Lindvall $\mathrm{O}$ \& Bjorklund A: The glyoxlic acid fluorescence histochemical method: a detailed account of the methodology for the visualization of central catecholamine neurons. Histochemistry $39: 97 \sim 127,1974$.

7) Fukui et al : Further confirmation of heterogeneity of the rat striatum: Different mosaic patterns of dopamine fibers after administration 
of Methamphetamine or reserpine. Brain Res 382: 81 86, 1986.

8) Tranzer $J$ \& Thoenen $H$ : Electron microscopic localization of 5-hydroxydopamine (3, 4, 5-trihydroxy-phenyl-ethylamine), a new false sympathetic transmitter. Experientia 23:743 744, 1967.

9) Hisa $Y$ et al : Ultrastructural and fluorescence histochemical studies on the sympathetic innervation of the canine laryngeal glands. Acta Otolaryngol 93: 119 122, 1982.

10) Shin et al: Vasomotor responses to laryngeal nerve stimulation. Arch Otolaryngol 91:257 261, 1970.

11) Hartenau $W$ \& Schwetz $F$ : Beobachtungen nach experimenteller Recurrensdurchtrennung bei der Katze. Arch Ohr-Nas-KehlkHeilk 169:242 245, 1956.

12) Arnold GE : Vocal rehabilitation of paralytic dysphonia. Arch Otolaryngol 70: 444 453, 1959.

13) Lemere $F:$ Innervation of the larynx. I. Innervation of laryngeal muscles. Am J Anat 51 : 417 437, 1932.

14) Lemere $F$ : Innervation of the larynx. II. Ramus anastomoticus and ganglion cells of the superior laryngeal nerve. Anat Rec 54:389 407, 1932.

15) Heinbecker $P$ \& O'Leary $J$ : The mammalian vagus nerve. A functional and histological study. Am J Physiol 106:623 646, 1933.

16) Evans DHL \& Murray JG: Histological and functional studies on the fiber composition of the vagus nerve of the rabbit. J Anat $88: 320$ 337, 1954.

17) Pressman JJ \& Kelemen G : Physiology of the larynx. Physoiol Rev 35:506 554, 1955.

18) Gacek RR \& Lyon MJ : Fiber composition of the reccurent laryngeal nerve in the cat. Ann Otol Rhinol Laryngol 85:460 471, 1976.

19) Hisa $Y:$ Fluorescence histochemical studies of the noradrenergic innervation of the canine larynx. Acta Anat 113: 15 25, 1982.

20) Sternberger LA et al: The unlabeled antibody enzyme method of immunohistochemistry. J Histochem Cytochem 18:315〜333, 1970.

21）井端泰彦：活性ペプチド及び神経伝達物質の免疫組 織化学的検出. 組織細胞化学1986（日本組織細胞化 学会編) 63〜 77, 学際企画, 東京, 1986.

22）川副みちるほか：喉頭におけるノルアドレナリン作動 性線維について。喉頭 1:93〜95, 1989.

23）千葉胤道：頭部および頸部の自律神経. JOHNS 5 ： 789 793, 1989.

24) Uddman $\mathrm{R}$ et al : Occurrence and distribution of VIP nerves in the nasal mucosa and tracheobronchial wall. Acta Otolaryngol 86:443 448, 1978.

25) Hisa $Y$ et al : Substance $P$ nerve fibers in the canine larynx by PAP immunohistochemistry. Acta Otolaryngol 100:128 133, 1985.

26) Hisa $Y$ \& Uno $T$ : Neurotransmitters in laryngeal protective function. Excerpta Medica (in press).

27）村松郁延，藤原元始：末梢自律神経系の神経伝達物 質. 神経進歩 $33 ： 216 \sim 225,1989$.

28) Morgenroth VA et al: Evidence for involvement of protein kinase in the activation by adenosine 3'5'-monophosphate of brain tyrosine 3-monooxygenase. J Biol Chem 250: 1946 1948, 1975.

別刷請求先 $\overline{\mathbf{T}} 602$ 京都市上京区河原町広小路上ル 京都府立医科大学耳鼻咽喉科学教室

久育男 